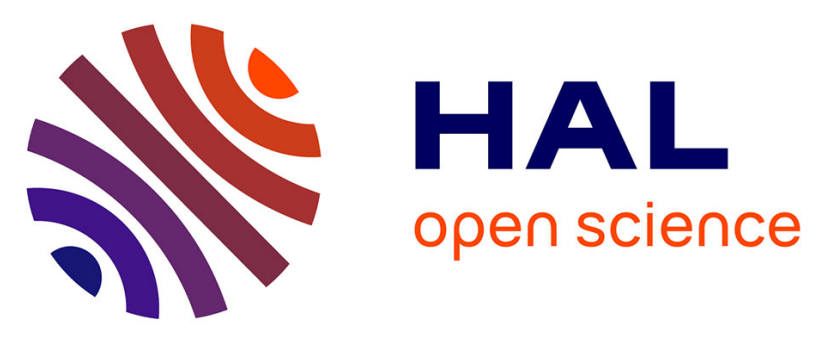

\title{
Confounding factors for variation of clozapine plasma levels: drug interactions with proton pump inhibitor or infectious etiologies?
}

Sophie Wagner, M. G. Varet-Legros, Claudine Fabre, Jean Louis Montastruc, Haleh Bagheri

\section{To cite this version:}

Sophie Wagner, M. G. Varet-Legros, Claudine Fabre, Jean Louis Montastruc, Haleh Bagheri. Confounding factors for variation of clozapine plasma levels: drug interactions with proton pump inhibitor or infectious etiologies?. European Journal of Clinical Pharmacology, 2010, 67 (5), pp.533-534. $10.1007 / \mathrm{s} 00228-010-0925-\mathrm{z}$. hal-00638575

\section{HAL Id: hal-00638575 https://hal.science/hal-00638575}

Submitted on 6 Nov 2011

HAL is a multi-disciplinary open access archive for the deposit and dissemination of scientific research documents, whether they are published or not. The documents may come from teaching and research institutions in France or abroad, or from public or private research centers.
L'archive ouverte pluridisciplinaire HAL, est destinée au dépôt et à la diffusion de documents scientifiques de niveau recherche, publiés ou non, émanant des établissements d'enseignement et de recherche français ou étrangers, des laboratoires publics ou privés. 


\section{Case report}

A non smoking 51-year-old woman was treated with clozapine since November 2005 for chronic psychosis. Moreover, she received cyamemazine (50mg/day), fluticasone-salmeterol (125mg-25mg, one to four times a day) an estrogen pill (levonorgestrel plus ethinylestradiol) and omeprazol (20mg per day) for gastrointestinal complaints. The last available plasma level measurement, in May 2009, was normal (clozapine $=496 \mu \mathrm{g} / \mathrm{l}$ and desmethylclozapine $302 \mu \mathrm{g} / \mathrm{l}$ respectively). No abnormal plasma levels of clozapine was underlined in medical reports during her exposure. In April 2010, she was hospitalized because an exacerbation of psychiatric symptoms (hallucination, agitation,...). At the beginning of hospitalization (second day), clozapine and desmethylclozapine plasma level were normal $(312 \mu \mathrm{g} / \mathbf{l}$ and $267 \mu \mathrm{g} / \mathrm{l}$ respectively) for a daily dose of $300 \mathrm{mg}$. On April $28^{\text {th }}$, omeprazol was replaced by esomeprazol, the sole PPI referenced in the drug formulary of the psychiatric hospital. Moreover, a probabilist antibioprophylaxia including amoxicilline+clavulanic acid was prescribed from April $29^{\text {th }}$ to May $6^{\text {th }}$ because of hyperthemia $\left(38^{\circ} \mathrm{C}\right)$ and her history of chronic bronchopneumopathy without identification of infectious agents. Pharmacokinetic monitoring two days later (April $30^{\text {th }}$ ) showed an increase of clozapine and desmethylclozapine plasma level $(1237 \mu \mathrm{g} / \mathrm{l}$ and $368 \mu \mathrm{g} / \mathrm{l}$ respectively). The rise of clozapine plasma levels did not change psychiatric status but led to neutropenia: polynuclear neutrophils (PNN) 
decreased from $9 \mathrm{G} / \mathrm{L}$ to $3 \mathrm{G} / \mathrm{L}$ on $3^{\text {th }}$ May. Suspecting an interaction, esomeprazol was stopped on $5^{\text {th }}$ May. Six days later, clozapine and desmethylclozapine plasma levels $(312 \mu \mathrm{g} / \mathrm{l}$ and $267 \mu \mathrm{g} / \mathrm{l})$ and PNN count $(8 \mathrm{G} / \mathrm{L})$ were normal. Omeprazol was not started again at this time.

\section{Discussion}

The first hypothesis suggested by doctors to explain the rise of clozapine plasma levels was the substitution of omeprazol by esomeprazole leading to the removal of induction of clozapine metabolism by omeprazol. In fact, both racemic omeprazol and its (s)-isomer, esomeprazol are metabolized by 2C19, 3A4 and 3A5 isoenzymes and inhibit CYP2C19 activity (4-5). However, it seems that omeprazol is the sole drug able to induce CYP1A2 activity supporting by clinical data (6) whereas drug interaction studies with esomeprazol did not find any potential interaction with drugs metabolised by CYP 1A2, 2A6, 2C9, 2D6 or 2E1 isoenzymes (4).

However, in our case, the effect of removal of omeprazol induction was seen so rapidly, 2 days after change of PPI: this delay was not very compatible with those reported for drug induction process depending upon the half-life of the enzyme. Then, another explanation for this variation could be the possible inflammatory states and infections. Some data report that serious respiratory infections could increase clozapine levels. The levels and activity of $\mathbf{P 4 5 0}$ are altered during infection and inflammation, apparently by cytokines release. (7-8)

In conclusion, in our case, drug interactions and/or infectious episodes could explain the variation of clozapine plasma levels. However, we should underline that chemical structure differences between racemic and isomer drugs could have an impact on drug metabolism. These pharmacokinetic particularities should kept in mind by medical staff, mainly in hospital, because of frequent substitution of drugs with the same pharmacological profile and indication.

\section{References}

1. Mookhoek E, Loonen (2004) Retrospective evaluation of the effect of omeprazole on clozapine metabolism. Pharm World Sci 26:180-182

2. Aronson JK (2006) Clozapine. In: Meyler's side effects of drugs The international encyclopedia of adverse drug reactions and interactions, $15^{\text {th }}$ edt. Oxford, United Kingdom, pp 823-841

3. Jaquenoud Sirot E, Knezevic B, Morena GP, Harenberg S, Oneda B, Crettol S, et al (2009). ABCB1 and cytochrome $\mathbf{P 4 5 0}$ polymorphisms: clinical pharmacogenetics of clozapine. J Clin Psychopharmacol 29:319-326

4. Andersson T, Hassan-Alin M, Hasselgren G, Röhss K, (2001) Drug interactions studies with esomeprazole, the (S)-isomer of omeprazole. Clin Pharmacokinet 40(7):523-37

5. Andersson T, Miners JO, Veronese ME, Tassaneeyakul W, Tassaneeyakul W, Meyer UA, et al. (1993). Identification of human liver cytochrome P450 isoforms mediating omeprazole metabolism. Br J Clin Pharmacol 36:521-530 
6. Frick A, Kopitz J, Bergemann N (2003) Omeprazole reduces clozapine plasma concentrations: A case report. Pharmacopsychiatry 36:121-12

7. Haack MJ, Bak ML, Beurskens R, Maes M, Stolk LM, Delespaul PA (2003). Toxic rise of clozapine plasma concentrations in relation to inflammation. Eur Neuropsychopharmacol, 13:381-385

8. Pfuhlmann B, Hiemke C, Unterecker S, Burger R, Schmidtke A, Riederer P, et al. Toxic clozapine serum levels during inflammatory reactions.J Clin Psychopharmacol, 29:392-394 


\section{Confounding factors for variation of clozapine plasma levels: drug interactions with proton pump inhibitor or infectious aetiologies? S Wagner ${ }^{1}$, MG Varet-Legros ${ }^{2}$, C Fabre ${ }^{3}$, JL Montastruc ${ }^{1}$, H Bagheri $^{1}$. \\ 1 Service de Pharmacologie Clinique, Centre midi-pyrénées de PharmacoVigilance (CRPV, de Pharmacoépidémiologie et d'informations sur le Médicament, EA 369, faculté de Médecine, 37 Allées Jules Guesde, 31000 Toulouse \\ 2 Centre Hospitalier Gérard Marchant, Department of Psychiatry, 31057 Toulouse cedex \\ 3 Centre Hospitalier Gérard Marchant, Department of Pharmacy, 31057 Toulouse Cedex}

\section{Background}

Clozapine is an atypical antipsychotic used in the treatment of schizophrenia in patients after failure of response of other anti-psychotic drugs because of its agranulocytosis risk. Because of frequent occurrence of gastrointestinal ADR, proton pump inhibitors (PPIs) are often prescribed in patients exposed to clozapine (1-2)

Clozapine is metabolized mainly through the $1 \mathrm{~A} 2$ isoenzyme, CYP3A4 only in patients with reduced CYP1A2 activity and moderate contribution of CYP2C19 (3). Agents that induce or inhibit CYP1A2 may increase or decrease, respectively the metabolism of clozapine (2): it's well known that smokers need to increase 2 fold the dose of clozapine compared with non-smokers because CYP1A2 induction by cigarette smoke (2). We report a case of change in clozapine metabolism after substitution of a racemic PPI, omeprazol by its (s)-isomer, esomeprazol associated to a possible infectious event.

\section{Case report}

A non smoking 51-year-old woman was treated with clozapine since November 2005 for chronic psychosis. Moreover, she received cyamemazine (50mg/day), fluticasone-salmeterol (125mg-25mg, one to four times a day) an estrogen pill (levonorgestrel plus ethinylestradiol) and omeprazol (20mg per day) for gastrointestinal complaints. The last available plasma level measurement, in May 2009, was normal (clozapine $=496 \mu \mathrm{g} / \mathrm{l}$ and desmethylclozapine $302 \mu \mathrm{g} / \mathrm{l}$ respectively). No abnormal plasma levels of clozapine was underlined in medical reports during her exposure.

In April 2010, she was hospitalized because an exacerbation of psychiatric symptoms (hallucination, agitation,...). At the beginning of hospitalization (second day), clozapine and desmethylclozapine plasma level were normal $\left(312 \mu \mathrm{g} / \mathrm{l}\right.$ and $267 \mu \mathrm{g} / \mathrm{l}$ respectively) for a daily dose of $300 \mathrm{mg}$. On April $28^{\text {th }}$, omeprazol was replaced by esomeprazol, the sole PPI referenced in the drug formulary of the psychiatric hospital. Moreover, a probabilist antibioprophylaxia including amoxicilline+clavulanic acid was prescribed from April $29^{\text {th }}$ to May $6^{\text {th }}$ because of hyperthemia $\left(38^{\circ} \mathrm{C}\right)$ and her history of chronic bronchopneumopathy without identification of infectious agents. Pharmacokinetic monitoring two days later (April $30^{\text {th }}$ ) showed an increase of clozapine and desmethylclozapine plasma level $(1237 \mu \mathrm{g} / \mathrm{l}$ and $368 \mu \mathrm{g} / \mathrm{l}$ respectively). The rise of clozapine plasma levels did not change psychiatric status but led to neutropenia: polynuclear neutrophils (PNN) decreased from 9G/L to 3G/L on $3^{\text {th }}$ May. Suspecting an interaction, esomeprazol was stopped on $5^{\text {th }}$ May. Six days later, clozapine and 
desmethylclozapine plasma levels $(312 \mu \mathrm{g} / \mathrm{l}$ and $267 \mu \mathrm{g} / \mathrm{l})$ and PNN count $(8 \mathrm{G} / \mathrm{L})$ were normal. Omeprazol was not started again at this time.

\section{Discussion}

The first hypothesis suggested by doctors to explain the rise of clozapine plasma levels was the substitution of omeprazol by esomeprazole leading to the removal of induction of clozapine metabolism by omeprazol. In fact, both racemic omeprazol and its (s)-isomer, esomeprazol are metabolized by 2C19, 3A4 and 3A5 isoenzymes and inhibit CYP2C19 activity (4-5). However, it seems that omeprazol is the sole drug able to induce CYP1A2 activity supporting by clinical data (6) whereas drug interaction studies with esomeprazol did not find any potential interaction with drugs metabolised by CYP 1A2, 2A6, 2C9, 2D6 or 2E1 isoenzymes (4).

However, in our case, the effect of removal of omeprazol induction was seen so rapidly, 2 days after change of PPI: this delay was not very compatible with those reported for drug induction process depending upon the half-life of the enzyme. Then, another explanation for this variation could be the possible inflammatory states and infections. Some data report that serious respiratory infections could increase clozapine levels. The levels and activity of P450 are altered during infection and inflammation, apparently by cytokines release. (7-8)

In conclusion, in our case, drug interactions and/or infectious episodes could explain the variation of clozapine plasma levels. However, we should underline that chemical structure differences between racemic and isomer drugs could have an impact on drug metabolism. These pharmacokinetic particularities should kept in mind by medical staff, mainly in hospital, because of frequent substitution of drugs with the same pharmacological profile and indication.

\section{References}

1. Mookhoek E, Loonen (2004) Retrospective evaluation of the effect of omeprazole on clozapine metabolism. Pharm World Sci 26:180-182

2. Aronson JK (2006) Clozapine. In: Meyler's side effects of drugs The international encyclopedia of adverse drug reactions and interactions, $15^{\text {th }}$ edt. Oxford, United Kingdom, pp 823-841

3. Jaquenoud Sirot E, Knezevic B, Morena GP, Harenberg S, Oneda B, Crettol S, et al (2009). ABCB1 and cytochrome P450 polymorphisms: clinical pharmacogenetics of clozapine. J Clin Psychopharmacol 29:319-326

4. Andersson T, Hassan-Alin M, Hasselgren G, Röhss K, (2001) Drug interactions studies with esomeprazole, the (S)-isomer of omeprazole. Clin Pharmacokinet 40(7):523-37

5. Andersson T, Miners JO, Veronese ME, Tassaneeyakul W, Tassaneeyakul W, Meyer UA, et al. (1993). Identification of human liver cytochrome P450 isoforms mediating omeprazole metabolism. Br J Clin Pharmacol 36:521-530 
6. Frick A, Kopitz J, Bergemann N (2003) Omeprazole reduces clozapine plasma concentrations: A case report. Pharmacopsychiatry 36:121-12

7. Haack MJ, Bak ML, Beurskens R, Maes M, Stolk LM, Delespaul PA (2003). Toxic rise of clozapine plasma concentrations in relation to inflammation. Eur Neuropsychopharmacol, 13:381-385

8. Pfuhlmann B, Hiemke C, Unterecker S, Burger R, Schmidtke A, Riederer P, et al. Toxic clozapine serum levels during inflammatory reactions.J Clin Psychopharmacol, 29:392-394 